November 2007

\title{
A Calamity in the Neighborhood: Women's Participation in the Rwandan Genocide
}

Reva N. Adler

Cyanne E. Loyle

Judith Globerman

\section{Recommended Citation}

Adler, Reva N.; Loyle, Cyanne E.; and Globerman, Judith (2007) "A Calamity in the Neighborhood: Women's Participation in the Rwandan Genocide," Genocide Studies and Prevention: An International Journal: Vol. 2: Iss. 3: Article 3.

Available at: https://digitalcommons.usf.edu/gsp/vol2/iss3/3

This Articles is brought to you for free and open access by the Open Access Journals at Digital Commons @ University of South Florida. It has been accepted for inclusion in Genocide Studies and Prevention: An International Journal by an authorized editor of Digital Commons @ University of South Florida. For more information, please contact digitalcommons@usf.edu. 


\title{
A Calamity in the Neighborhood: Women's Participation in the Rwandan Genocide
}

\author{
Reva N Adler \\ Department of Medicine, University of British Columbia, \\ Cyanne E Loyle \\ PhD Candidate, Department of Political Science, University of \\ Maryland and \\ Judith Globerman \\ Institute for Health Promotion Research, University of British \\ Columbia
}

Although public-health-based violence-prevention trials have been successful in a variety of high-risk settings, no study has addressed the prevention of genocide, a form of population-based catastrophic violence. In addition, little is known about women who participate in genocide, including women's motivations for active participation in hands-on battery, assault, or murder. In order to explain why women assaulted or murdered targeted victims during the 1994 Rwandan Genocide, we interviewed ten Rwandan female genocide perpetrators living in prisons and communities in six Rwandan provinces in 2005. Respondents' narratives reveal two distinct pictures of life in Rwanda, separated by an abrupt transition: Life prior to 6 April 1994 and Life during the 1994 genocide (6 April-15 July 1994). In addition, respondents described four experiential pressures that shaped their choices to participate in the 1994 genocide: (1) a disaster mentality; (2) fear of the new social order; (3) confusion or ambivalence about events on the ground; and (4) consonance and dissonance with gender roles. The unique combination of these factors that motivated each female genocide participant in Rwanda in 1994 would shift and evolve with new situations. These findings may have implications for understanding and preventing catastrophic violence in other high-risk jurisdictions.

\section{Introduction}

Deaths due to genocide have exceeded war-related deaths in every historical period, and were eight-fold higher in the twentieth century than in the sixty-nine preceding centuries. ${ }^{1}$ This pattern has persisted into the twenty-first century as attacks on civilians by governments and insurgents continue around the world. ${ }^{2}$ The rate of genocide-related mortality is extremely high, far greater than rates for other global pandemics, including HIV/AIDS and malaria. ${ }^{3}$ The health sequelae for survivors of genocide include solid organ disease; neurological dysfunction; and psychiatric illness that may be chronic, lifelong, and intergenerational, increasing the burden of disease in affected communities for decades after the killing has ended. ${ }^{4}$ In order to accelerate death and injury within victimized groups, genocidal regimes often target health-care infrastructure and personnel for destruction, ${ }^{5}$ rendering them powerless to address even basic public-health requirements amidst spiraling need. The global health economy is invariably strained when scarce international resources are diverted out of a necessity to address pressing crises in conflict zones. ${ }^{6}$

Reva N Adler, Cyanne E Loyle and Judith Globerman, "A Calamity in the Neighborhood: Women's Participation in the Rwandan Genocide," Genocide Studies and Prevention 2, 3 (November 2007): 209-234. (C) 2007 Genocide Studies and Prevention. doi: 10.3138/gsp.2.3.209 
The past fifteen years have seen at least three major episodes of genocide in close succession; the most recent, in Darfur, continues at present without resolution or international agreement on a strategy for peace. ${ }^{7}$ At the outbreak of each new event, health professionals, researchers, and educators have called for diplomatic, military, and humanitarian intercession when violence is imminent or when it is first unleashed. ${ }^{8}$ Within a public-health construct, this form of intervention is known as secondary prevention and falls into much the same category as urgent care in a hospital for someone having a heart attack. This form of intervention may prevent the death of the patient, and may ameliorate some disabilities when a problem is well established, but, by definition, it cannot prevent the underpinning health problem from developing. Secondary prevention of any problem is predictably expensive, as it is an unplanned emergency response and relies heavily on costly technology and personnel in accomplishing its goals.

As the science of violence prevention enters the global health mainstream, such international organizations as the World Health Organization (in the World Report on Violence and Health) and the International Commission on Intervention and State Sovereignty (in their report The Responsibility to Protect) have accelerated calls for the primary prevention of extreme collective violence by studying its root causes and developing anticipatory interventions that prevent extreme violence from erupting. ${ }^{9}$ Primary prevention programs lower the likelihood of health problems by addressing specific risk factors that contribute to those problems, years in advance of untoward consequences. Using the example of heart attack, primary prevention would include early diagnosis and treatment of problems that contribute to the development of heart disease over the long term, such as high blood pressure and high cholesterol. Universally, primary prevention is more effective and less expensive than secondary methods, as it is a carefully planned response, addresses problems that are cheaper and easier to treat, and forestalls the costly disability associated with entrenched pathology.

One approach to the primary prevention of genocide, suggested by successful public-health violence-prevention trials in a number of other high-risk milieus such as prisons $^{10}$ and inner-city neighborhoods, ${ }^{11}$ is based on identifying behavioral and attitudinal risk factors for violence among individuals and groups years before turmoil arises, then "treating" these risk factors through programs of family, classroom, community, and media-based education. ${ }^{12}$ The goal of violence-prevention programs is to lower the risk for hands-on violence among average community members and groups during times of social upheaval. To optimize efficacy, such initiatives are customarily developed to be synergistic with structural efforts to lower violence, such as improved policing, criminal penalties, and betterment of social conditions.

There have been few studies addressing the attitudes and beliefs that lead average citizens to attack or kill unarmed civilians when goaded by genocidal regimes, and no study to date has targeted modifying such risks in nations known to be at high risk for catastrophic violence. Much of the published material in this area has been theoretical or observational in design, and few authors have conducted research directly with persons who have committed hands-on violence during a genocide or other forms of catastrophic violence. ${ }^{13}$ This neglected avenue of inquiry is a critical element of an interdisciplinary, inclusive approach to genocide prevention and provides the foundation for the research discussed here. 
The women's interviews conducted for the study Addressing the Root Causes of Genocide, Phase 1 (ARC-G Phase 1), are analyzed in this article. The intellectual framework for ARC-G, discussed in detail elsewhere, ${ }^{14}$ may be briefly summarized as four interrelated segments:

Phase 1: To identify the attitudinal risk factors for genocidal violence among individuals and groups in a retrospective sample of genocide perpetrators in Rwanda

Phase 2: To identify the same risk factors, in real time, in a sample of persons at high risk for genocidal behavior at present

Phase 3: To craft and implement public-health-based programs to lower the risks of violence in the population described in Phase 2

Phase 4: To evaluate and refine Phase 3 interventions

The specific aims of the women's subset of ARC-G Phase 1 (ARC-G Phase 1W) were to (a) develop a theoretical model explaining why rank-and-file Rwandan women assaulted or murdered targeted victims during the 1994 Rwandan Genocide and (b) identify a group of attitudinal risk factors for genocidal behavior in individuals and groups that would have the potential to be modified in long-range public-health-based initiatives directed at preventing genocide in future high-risk settings.

\section{Background and Context}

Worldwide, most crimes against the person are perpetrated by men. ${ }^{15}$ As a result, genocide is more often than not characterized as a male crime, ${ }^{16}$ the outcome of contemporary notions of masculinity, ${ }^{17}$ and, by some authors, as a specifically gendered form of catastrophic violence. ${ }^{18}$ In contrast, women are frequently portrayed as victims of genocide - through structural violence endangering the many domains of human security, through interpersonal violence resulting in injury or death, and through sexual violence that may be either random or organized. ${ }^{19}$

It follows, therefore, that the investigators who have explored the motivations of genocide perpetrators have focused principally on male participants. ${ }^{20}$ Much less is known about women who participate in genocide, including the structural circumstances that lead women to perpetrate genocide-related crimes, women's roles in initiating and sustaining catastrophic violence, and women's motivations for active participation in hands-on battery, assault, or murder.

Recent scholarship has attempted to elucidate the global macro-environment surrounding many of the international episodes of catastrophic violence that occurred between 1990 and 2000. For example, the collective violence in the African Great Lakes region in the 1990s may, in part, be traced to the increase in structural violence experienced in that region during the preceding decades. A steep rise in oil prices during the 1970s gave way to a global economic downturn, falling commodity prices, increasing national debts, and structural adjustment. ${ }^{21}$ These trends had a disproportionate impact on poorer countries, contributing to crises of legitimacy among ruling elites. ${ }^{22}$

The results of such global pressures on the security environment within tenuous or failing states are numerous. In an environment of economic recession and vanishing employment, leaders may choose to entice unemployed young men into military service, while at the same time making scapegoats of minority groups in an attempt to divert attention away from government culpability. ${ }^{23}$ Authors point to premonitory 
increases in arms stockpiles, the expansion of traditional military forces, and the amplification of exclusionary or divisive ideology as signaling impending collective conflict. ${ }^{24}$ The national consciousness may become focused on ethnic "purity," or on cleansing the nation of persons seen as alien or as dangerous to the nation's vitality. ${ }^{25}$ Men may be called upon to fight or kill for the sake of "the nation" but, most especially, to kill to protect women and children, who are envisioned in the national consciousness as defenseless non-combatants. Women, on the other hand, may be called upon to support sons, brothers, and partners in their masculine role as "defenders of national security."

These conditions were no less present in Rwanda between 1990 and 1994, during the period of the Rwandan Patriotic Front (RPF) invasion from Uganda and the introduction of a multi-party political system by the 1991 constitution. ${ }^{26}$ However, evidence from the Rwandan Genocide compels us to re-examine the specific roles of women in collective ethnic violence.

Women's involvement in the planning and implementation of the 1994 genocide at all societal levels has been well described. ${ }^{27}$ Women's participation ranged from working as main architects of the violence to acting as individual killers in small communities. Most commonly, women denounced victims and looted victims' homes as well as their bodies. ${ }^{28}$ Much less frequently, women killed directly, with a variety of modern and more traditional weaponry. ${ }^{29}$

This characterization of women's participation is supported by available statistics. Only one woman, Pauline Nyiramasuhuko, has been indicted by the International Criminal Tribunal for Rwanda (ICTR), on charges that she incited troops to rape and kill hundreds of women in the university town of Butare during the genocide; her trial continues at the time of writing. ${ }^{30}$ Statistics from the Rwandan justice system indicate that in 2004 approximately 3,000 women, representing some $3.4 \%$ of the Rwandan prison population, were incarcerated in Rwandan prisons for genocide-related crimes; the significant majority of these women have been charged either as accomplices to murder or assault (for denouncing victims or roaming with attack groups) or as thieves (for looting during the genocide). There have been no judicial executions in Rwanda since 1998; only six women $(0.2 \%)$ in total have been sentenced to death for genociderelated crimes, and only one woman was in fact executed. The acquittal rate for women charged with genocide-related crimes is $40 \% .^{31}$

A comparison to statistics for men in Rwanda makes clear the differences in handson involvement in the 1994 genocide. For example, in 2002 alone, 1,909 men were adjudicated for genocide-related crimes dating to 1994; seventy (3.6\%) received the death penalty, and 528 (27.6\%) were acquitted. ${ }^{32}$ In 1998, twenty-one Rwandan men were found guilty of genocide-related crimes, sentenced to death, and publicly executed. ${ }^{33}$

Much of what we know about female genocide participants in all of these realms has been gathered from the eyewitness accounts of victims and bystanders; little has come from the perpetrators themselves. ARC-G Phase $1 \mathrm{~W}$ was designed to address this gap, as well as to explore the thoughts, feelings, attitudes, and beliefs of women who perpetrated hands-on violence during the Rwandan Genocide.

\section{Methods}

\section{Study Design and Participants}

The sample was designed to represent the rank-and-file population of civilian women who participated in crimes against the person but were not political, military, or 


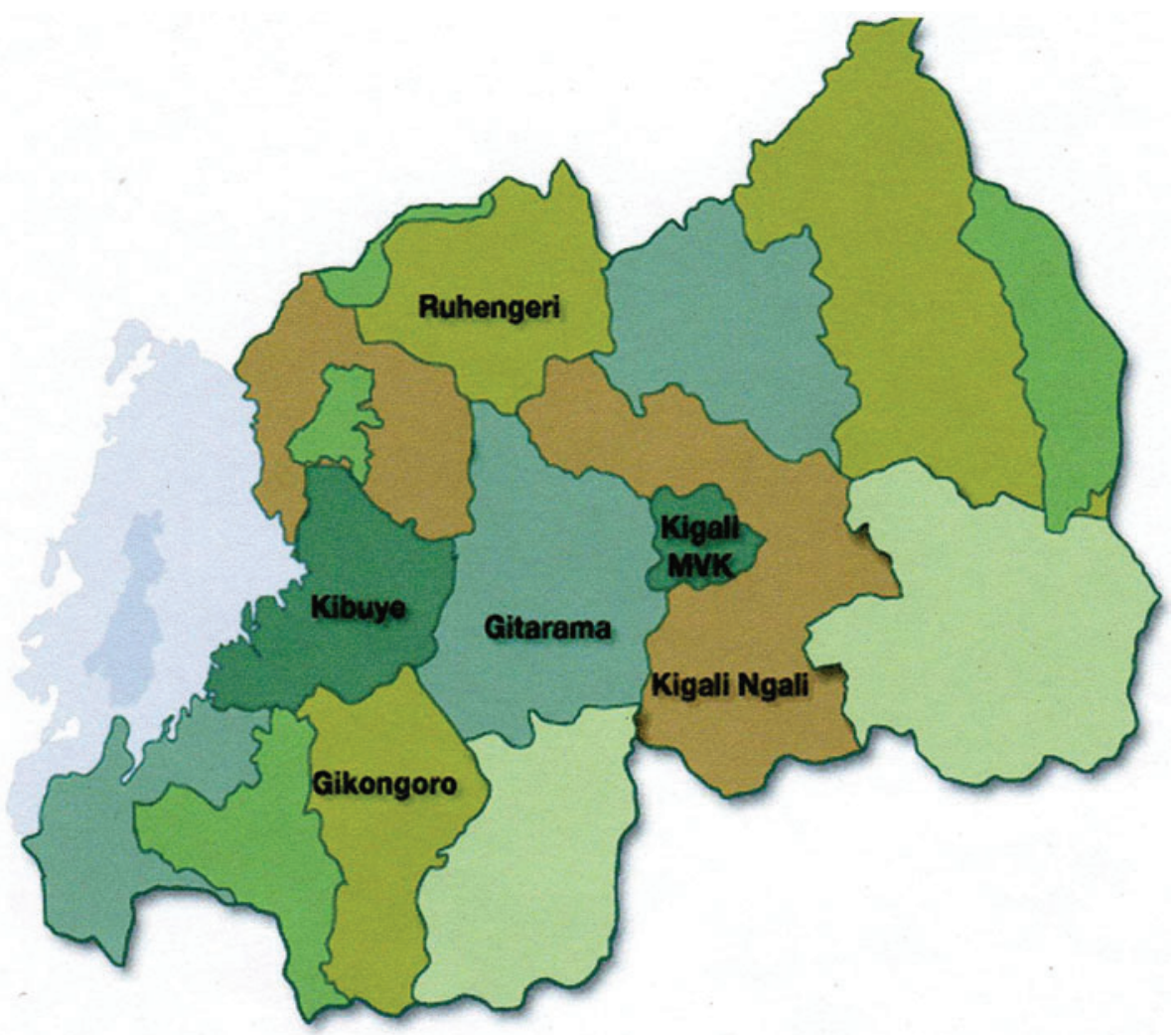

Figure 1. Research sites (on map of Rwanda with 2005 provincial borders) ${ }^{37}$

attack-group leaders during the 1994 Rwandan Genocide. The method used was grounded theory, a qualitative technique used to form a testable theory about the phenomena being studied based on the constant comparison of data within participant interviews. At the conclusion of theoretical sampling, ten women who confessed to or were convicted of Category 2 (murder) or Category 3 (assault) genocide crimes under Rwandan law participated in the study. Study participants ranged from adolescence to middle age in 1994. The sample comprised both urban and rural dwellers. In keeping with grounded theory, sampling concluded when all categories of interest were saturated (i.e., when researchers deemed that no new information on a particular phenomenon was emerging from subsequent interviews). Theoretical sampling was employed to capture target-population diversity. Selective and discriminate sampling was used to ensure exploration of evolving patterns. In accordance with the constant comparative method, new interviewees were identified to expand upon emergent and absent themes. ${ }^{34}$

Because rates of literacy ${ }^{35}$ and telephone ownership ${ }^{36}$ are low in Rwanda, thirdparty opinion leaders in prisons and communities in six Rwandan provinces-Kigali, Kigali Ngali, Gitarama, Ruhengeri, Kibuye, and Gikongoro (see Figure 1)—recruited study participants by word of mouth between February and April 2005. Opinion leaders gave or read invitation letters to community members who met the study criteria and obtained verbal permission for researchers to approach potential participants in person (as none had phones or postal access). Interested individuals 
were provided with further information by the study team and given at least twentyfour hours to consider their participation. All study participants took part in informed consent procedures under a UBC Behavioural Research Ethics Board certificate.

\section{Interviewers and Interview Procedures}

The interview team, whose members were supervised during data collection, consisted of five trained, multilingual interviewers self-identifying as members of either Hutu or Tutsi cultural groups and originating from four of Rwanda's ten provinces according to 1994 boundaries. Data collection was carried out via a two-hour face-to-face semistructured interview, using Grant McCracken's long interview method. ${ }^{38}$ The interview guide was developed based on previous participant observation, key informant interviews, a focus group, and pilot interviews and took a "life history" format. The interview guide evolved as the interviews progressed to test and confirm emerging themes and patterns.

All interviews were audio-recorded. Because audio-recording is prohibited inside Rwandan prisons, special arrangements were made with the Ministry of the Interior to interview prisoners in offices attached to but not officially located within the prison enclosure. Interviews were conducted in the language of choice of the participant, which for all participants was Kinyarwanda. Once interviews were completed, a separate team of multilingual translators listened to the audio-recordings and, in a single step, transcribed the interviews and translated them into English. Backtranslation, retranslation, and spot-check translation were used to optimize precision. ${ }^{39}$

\section{Data Analysis}

Transcribed audio-recordings were loaded into Atlas.ti software and analyzed by two researchers. Transcripts were examined according to McCracken's method, using an editing approach to text analysis in five stages:

(1) Detailed examination of individual transcripts for statements treated independently of each other

(2) Analysis of individual statements for meaning

(3) Identification of themes and patterns

(4) Search for inter-theme consistency and contradictions

(5) comparison of themes between interviews). ${ }^{40}$

Following analysis of each transcript and development of data codes, the research team identified and tested emergent theory. ${ }^{41}$

\section{Results}

Participant characteristics are shown in Table 1. All respondents reporting "no income" were students. No participant experienced prolonged food insecurity in 1994. Respondents' narratives reveal two distinct pictures of life in Rwanda, separated by an abrupt transition: Life prior to 6 April 1994 and Life during the 1994 genocide (6 April15 July 1994). For each time period, respondents described a distinct set of environmental themes underpinning their everyday lives and thereby informing their beliefs, behavior, and decisions. In addition, respondents described four experiential pressures that shaped their choices to participate in the 1994 genocide: (1) a disaster mentality; (2) fear of the new social order; (3) confusion or ambivalence 
Table 1. Demographic characteristics of ARC-G Phase 1W respondents

\begin{tabular}{ll}
\hline & $\begin{array}{l}\text { Respondents } \\
(N=10)\end{array}$ \\
\hline Age (years) & \\
Range & $15-53$ \\
Median & 17.5 \\
Mean & 22.5 \\
Residence & \\
Urban & 5 \\
Rural & 5 \\
Marital Status & \\
Single & 5 \\
Married & 5 \\
Ethnicity & \\
Tutsi & 1 \\
Hutu & 9 \\
Education (years) & \\
Range & $1-16$ \\
Median & 6 \\
Mean & 5.8 \\
Annual Income (1993 $\$$ US) & \\
Range & $0-2315.00$ \\
Median & 0 \\
Mean & 534.57 \\
Occupation & \\
Farmer/landowner/herder & 5 \\
Student & 2 \\
Merchant at market & 1 \\
Accountant & 1 \\
Civil servant & 1 \\
\hline
\end{tabular}

about events on the ground; and (4) consonance and dissonance with gender roles. The environmental themes reported here were influential among individuals and groups not only during the genocide but also for years before it started and, most likely, for years afterward. Experiential pressures emerged during the early days of the genocide and, for some respondents, persist into the present day. The unique combination of these factors that motivated each female genocide participant in Rwanda in 1994 would shift and evolve with new situations.

\section{A Brief Description of Study Participants}

Respondent 1: A student who led the Interahamwe (Hutu Power militia) to a house where victims were living

Respondent 2: A student who participated as a witness in an attack group

Respondent 3: A teenaged farmer who denounced victims being hidden by her family

Respondent 4: A teenaged farmer who denounced a child hiding in her neighborhood

Respondent 5: A teenager who denounced a friend from school who was hiding in the bush 
Respondent 6: A middle-class businesswomen who did not want to discuss the crimes
she was charged with

Respondent 7: An Interahamwe member who admits to murdering targeted victims during the genocide

Respondent 8: A merchant who denounced roommates

Respondent 9: A local official who distributed weapons and detained victims

Respondent 10: An educated worker in a large business who denounced neighbors

\section{Environmental Themes}

\section{Life prior to 6 April 1994}

Under Rwandan law prior to 1994, men sat as heads of household and women were barred from inheriting property, entering into any legal agreement, or opening a bank account without spousal permission. On average, women were less educated than men, and few women held positions of authority within any echelon of government. ${ }^{42}$

In Rwandan communities prior to 1994, gender roles for women emphasized hard work without complaint, homemaking, rearing and disciplining children, faithfulness to partners, and (for women with farms or gardens) making a success of subsistence agriculture. Some authors point to subtle changes in the conception of "femininity" in Rwanda starting with the national pogroms of 1973, when women first participated in "national security" activities by harassing, denouncing, or assaulting Tutsi women in their schools, workplaces, and communities. ${ }^{43}$ Nonetheless, the majority of Rwandan women in 1994 adhered to the traditional expectations of homemaking, childrearing, and creating community between households.

On the other hand, men were seen as family "breadwinners." Rwandan men were respected for "observing much and saying little," providing financially for their wives, educating their children, protecting their families, and defending their communities (from external threats as well as from more commonplace violence). Men made up thelarge majority of Rwandan soldiers, legislators, and municipal officials. Men were responsible for most national and local security functions before and during the 1994 genocide.

The narratives of female participants in the Rwandan Genocide elaborate a picture of Rwandan life before 1994 that was centered on close-knit neighborhoods, community cohesion, and the principle of mutual aid. Families, regardless of ethnicity, cooperated with each other in cultivating crops, maintaining infrastructure, and sharing resources in good times; in times of emergency, they relied on one another to share food when crops failed, and to support widows and orphans in need:

Respondent 4: We invited each other to help in cultivating one's piece of land in turns. We invited each other to weddings and even helped each other in hard times, such as carrying the sick to hospital or burying the dead ...

Respondent 10: We got along with our neighbors. We had no problem with them. We shared what we had. I used to call some of them my fathers-in-law and my godmothers. I felt I was really in a family.

Although most respondents describe a life free of ethnic considerations or conflicts, women from the north of Rwanda (where the ruling MRND party originated) report a background regional climate based on exclusionary ideology and "hidden" ethnic tensions:

Respondent 8: Young people weren't allowed to marry Tutsis, and leaders discouraged such weddings. 
Respondent 6: Before the genocide, people were interacting, but not satisfactorily. The war that broke out in 1994 had also broken out in the 1960s and 1959 , and it just kept on going, though some people tried to hide it. So, whenever and wherever you went to settle down, you could see that ethnic considerations were instilled in the people...

When the RPF invaded Rwanda in 1990, few respondents noted any change in day-to-day community relationships, although northerners, along with residents of Kigali, report that prominent Tutsis, as well as families whose children had left Rwanda to join the RPF, were gradually marginalized as "enemy collaborators." Tutsi and Hutu supporters of the RPF were forced underground:

Respondent 8: After the Inkotanyi [the RPF] invaded the country, Tutsis were no longer respected as people who had rights as citizens.

Respondent 6: The people who wanted to follow the RPF political party working outside of the country had to do it secretly... We simply felt that we had been invaded by inyenzi [cockroaches].

With the introduction of multi-party politics in Rwanda in 1991 tensions within communities intensified, both between Rwandan ethnic groups and also among members of the same ethnic group who joined different political parties. Animations (political rallies aimed at recruiting and "energizing" party members) became common in most parts of the country. Battles over political influence frequently turned violent. However, although Tutsi Rwandans became more of a national target during this period, respondents report that relationships between neighbors of all ethnic groups remained more or less intact:

Respondent 1: Let me say a bit about the multi-party period, just before the killings started. At that time, there were many parties, all of them officially sanctioned, but the members of one party would attack members of another simply because they were jealous that certain parties were attracting more members... . This was all about jealousy and greed.

Respondent 7: We [neighbors] interacted agreeably and we had no misunderstandings, but thereafter we disengaged ourselves. This problem arose because of our political involvements.

Political discord on the community level also divided some families:

Respondent 3: My dad had nothing against [Tutsis], but my brother was against Tutsis because he was with the killers... People used to call Tutsis inyenzi [cockroaches], but in my family Tutsis were respected... My dad used to tell us that he didn't believe what people were saying about Tutsis, and that they were human beings like us, and that it wasn't true that they wanted to kill Hutus.

\section{Life during the 1994 Rwandan Genocide}

The narratives of our respondents change abruptly as they begin to speak about 6 April 1994, when the plane carrying Rwandan President Juvénal Habyarimana (as well as the president of Burundi, Cyprian Ntayamira), was shot down. Respondents experienced this event as a critical assault on national sovereignty, placing Rwanda in an official state of emergency. Interim government leaders swiftly moved to blame the incident on the RPF, ${ }^{44}$ and all Rwandan Tutsis and politically moderate Hutus were just as swiftly labeled "enemy collaborators."

The downing of Habyarimana's plane had the immediate effect of increasing the militarization of the entire country, a move pre-planned by Hutu Power militants 
months earlier. ${ }^{45}$ Militarization was framed as critical to "national security" and encompassed not only the armed forces but also a large proportion of Rwandan civil society. Over the next months, men and boys without military experience were recruited, trained, cajoled, and coerced to join civilian militias acting as extensions of the Rwandan military. In early April, the Rwandan armed forces, civilian militias, and their local supporters proceeded to round up and kill Tutsi men as well as prominent opponents of the Hutu Power movement. Later, women, girls, and younger children were also targeted. As for the rest of the population, non-targeted civilians, particularly women and children, were instructed to remain indoors and "out of harm's way."

Respondent 8: News of the death of the president begun to spread the following morning, and the Interahamwe were going around telling people that their enemies had killed their president. Leaders ordered people not to leave their houses.

Respondent 9: Personally, I never knew that a war would start. We shared everything, and then abruptly we heard that they had shot down Habyarimana's plane. I think this was the cause of the killings that took place.

Respondent 2: People used to say that Tutsis were spying for the Inkotanyi [the RPF] and that the Inkotanyi wanted to kill Hutus ... Sometimes people said they were killing inyenzi [cockroaches], as if they were not killing human beings, and that to kill Tutsis was like self defense, because people were saying that Tutsis were about to kill Hutus.

After early April 2004, governance in Rwanda devolved to a complex network of government, military, and Interahamwe extremists working in loose affiliation, as well as individually, at national, regional, and local levels. During the genocide, ad hoc leaders in all social strata mobilized citizens to denounce, rob, and kill targeted Tutsi and Hutu victims-by planning and importing weapons from abroad, by assassinating formal leaders who would not cooperate with the Hutu Power agenda, by commanding the Rwandan armed forces and Interahamwe militias to attack and kill unarmed civilians, by disseminating misinformation about the RPF and Tutsi civilians at the national and local levels, and by bribing and coercing average civilians to participate in the mayhem. The impact of manipulative and destructive leadership on the attitudes, beliefs, and behavior of most Rwandans during the genocide was noted by a large majority of respondents:

Respondent 4: I think it's the leadership that was in place [that is to blame for the genocide], because if they had punished those who killed first as an example, the killings wouldn't have escalated. However, the leaders in place then were very greedy people, and they wanted to stay in power.

[Interviewer]: Who do you think could have stopped the killings but did nothing ...?

Respondent 7: The leaders, because they helped us and incited us to continue the killings, while they were the ones who were supposed to condemn such atrocious acts.

Respondent 8: Let me tell you, leaders played a big role in the killings, because they came and told us that our Tutsi neighbors were going to kill us, and that [the Tutsis] had guns in their houses... In addition, many of us were poor, and [our leaders] were telling us that we could keep our neighbors' belongings.

\section{Experiential Pressures: Explaining Calamity}

As previously mentioned, the female respondents who participated in ARC-G Phase $1 \mathrm{~W}$ describe four distinct experiential pressures driving their decisions to participate 
in hands-on violence after the death of Habyarimana: (1) a disaster mentality, (2) fear of the new social order, (3) confusion or ambivalence about events on the ground, and (4) consonance and dissonance with gender roles. Each of these will be discussed here in some detail.

\section{Disaster Mentality}

Within hours of the downing of Habyarimana's plane at Kanombe Airport, women report, many sectors of Rwandan society went into an immediate state of crisis. A large proportion of female respondents describe knowing that something devastating had happened not only to their country but also to their communities and their everyday lives. Faced with this unparalleled disaster, and fearing that Rwanda was ungovernable without Habyarimana, most respondents felt the urgency of finding new answers to their predicament.

This omnipresent mood of disaster had a variety of effects on the emotional states of respondents; some report feeling unnerved or panicky, while others felt despondent and hopeless. Still other respondents remember feeling outraged; they quickly moved to revenge Habyarimana's death by attacking unarmed Tutsi civilians, all of whom the government characterized as RPF collaborators and thereby responsible for the death of the president.

Respondent 7: I heard on the radio how the plane was shot down, that citizens weren't supposed to scatter and a curfew was imposed... After hearing this, I never left home, thinking that if I did I would die, leaving my kids to be orphans, which wouldn't have been the right thing to do.

Respondent 6: The average person wanted to die, for life had become meaningless. Can you imagine seeing a man slaughtering his fellow men?... The country you saw, it belonged to the beasts.

Respondent 8: We people [from the north and west of Rwanda], we were really sad because we had lost our president, who was so important to us ... and we were revenging his death. People from other regions were jealous of us [because President Habyarimana had favored people from his own northwestern origins] and we knew it, so when the president died we felt as if they were in one way or another responsible... People really hated Tutsis because everyone knew that they were in support of Inkotanyi. We thought that Tutsis would all be killed, and that nothing would happen afterwards, that no one would be punished for having killed them.

\section{Fear of the New Social Order}

Rwanda's social fabric deteriorated in the post-Habyarimana period, as violence accelerated into chaos. Many respondents describe a social environment that was incomprehensible, dangerous, and terrifying; despite the advancing RPF and ubiquitous anti-Tutsi rhetoric, women most feared fellow Hutus involved in genocidal activities.

Respondent 4: I was terrified because there were screaming and wailing all over the place, and whistles were blown and men ordered to go to night patrols and roadblocks... I even asked why they were killing the Tutsis and they told me that Tutsis had to die. I always thought that [Tutsis] were innocent and being victimized.

Respondent 6: Whenever something made a slight noise, you felt [the extremists] were coming to kidnap you. You could see abducted people being led away... You felt you could not believe anyone. You did not even 
understand how such things could be happening. Things were unbelievable. What happened in April was extremely bad.

Although women were directed to remain at home, they were also expected to maintain the traditional female roles of running the household, caring for children, and supporting the men of the family, all in increasingly perilous surroundings. Obtaining food and water became progressively more dangerous amid escalating community violence, and women had difficulty moving about freely for fear of being injured or killed in the melee. This had a multiplicative effect on women, who felt increasingly under threat even though they were not members of targeted minority groups.

Respondent 1: ... The place where we used to fetch water was too far away and we were supposed to pass by roadblocks. The document certifying that I didn't have a national identity card (because I was a minor) was denied to me. So one day, they arrested me and ordered me to sit at the roadblock where they asked me a lot of questions trying to find out if I was really Hutu.

Respondent 2: My role was that I witnessed people killing someone... I saw a group of people going down to the river with a man and [I saw them] kill him there... Of course, there were people who just watched others being killed, and had the means to save them [but did nothing].

Respondent 2: I think [people] were afraid to stop the killings, fearing to be associated with Tutsis.

Some respondents found it necessary to find new ways to ensure their safety as well as to procure the necessities of life for themselves and their families.

Respondent 1: The following day, a soldier, whom I knew, came and said, "I don't want you to be short of water. That's why I suggest you always to go with our people"... I was scared. The following day he told me, "Before you fetch water, come to see me so I can lend you my military shirt." So I agreed. I put that shirt on every time I needed to fetch water. I always went with his people. Sometimes, it was very hard to pass depending on which Interahamwe were on the road... Some of them were more terrible than soldiers.

\section{Confusion or Ambivalence about Events on the Ground}

Homebound and fearful, Rwandan women faced significant obstacles when they tried to gather information and frame opinions about the escalating violence in their communities. This, in turn, placed women at a disadvantage in trying to construct a comprehensive picture of their "new world," as well as in making informed decisions about their personal actions under the circumstances.

Respondent 1: ... Women and girls are supposed to stay at home and look after the house. Men are the people who spend all their time walking and going to bars... People say that a lot of things [during the genocide] took place in bars. In Rwandan culture, no woman can spend a night in a bar. I think the difference lies in the fact that women are supposed to stay home, but men are always moving.

At the same time, however, women were also expected by armed killers to participate in the genocide by denouncing victims, looting and burning local properties, and lending support to the homicidal agenda of extremists. The majority 
describe confusion regarding what to think, how to feel, and whom to believe about the unfolding genocide.

Respondent 2: In our area, the situation was normal and calm, but at the end of April some people started to flee. ... A few days later some people in our area started to sing songs about exterminating [Tutsis]...I couldn't understand how people could kill each other without a reason.

Respondent 1: I heard people saying ... that [Tutsis] were enemies of the state.... The people being killed were our neighbors, and the family had children I grew up with, went to school with. ... So how can someone say that a fourteen-year-old kid is an enemy of the state?... People kept saying that Tutsis were state enemies, but there was nothing, either in our conversations or our daily lives, proving that it was true.

Similarly, many respondents describe their involvement during the genocide as being haphazard or situational, rather than informed by thoughtful deliberation or strongly held views. Some women describe responding "in the moment" to provocations for violence, without significant forethought or malice toward victims.

Respondent 5: There was once when I went to fetch water down a hill [that] I heard people from across the other hill screaming. Then a girl came running and she hid in a bush that was nearby. I saw her and didn't say a word. ... I then started heading home, but before reaching home I encountered some other kids my age who asked me about the screaming. I told them what had happened [and] where she was hiding. I didn't know they would give her up. ... I went home and after a short while one of my cousins passed by our compound with the girl in his arms and [he] ... killed her. I confessed because I knew that if I had kept my mouth shut... nothing would have happened to her ...

[Interviewer]: Personally what were your feelings then?

Respondent 5: I was terrified and miserable."

Respondent 3: My dad's Tutsi friend was hiding in our house and they kept asking my father if that man was there, but always he denied it. One day I told my brother that the man they were looking for was hiding in our house, and they went and found him there. ... I didn't do it because I hated him, or Tutsis, but because my brother promised me that he wouldn't kill him and gave me some gifts. ... Eventually they took [my father's friend] away and killed [him]. That's when I started to feel guilty and my heart was telling me that I had committed a sin.

Respondent 9: A man came with his assault group and I heard that he had family ties with Habyarimana. He came and said to me severely, "You, local leader, I want you to protect these people." I thought that killings wouldn't reach our home area. When he came back he gathered the people in my compound and clubbed them to death. ... I was shocked because I didn't know him and didn't know his intentions. He went for one minute and came back. I never knew that he was going to kill them.

\section{Consonance and Dissonance with Gender-Based Expectations}

While many women attribute their involvement in the 1994 genocide to spontaneous or poorly considered behavior, some participated deliberately and with conviction. The ambient themes that conditioned Rwandan women to participate willingly in the genocide, as discussed above and elsewhere, include destructive ideology, rapid militarization of civil society, fear of extremist governance, greed, and 
overpowering social upheaval. Men and women alike were caught up in the "total environment" imposed by these mutually reinforcing factors. ${ }^{46}$

Women participated in the Rwandan Genocide one of two ways: more "passively," by cheering killers on, looting property, and denouncing victims; or more "actively," by working with attack groups and personally assaulting targeted individuals. The former group of women, comprising the large majority of willing genocide participants, conducted themselves within the limits forged during the 1973 pogroms. While remaining within traditional gender norms with respect to spouse, home, and family, these women nevertheless lent support to the eliminationist Hutu Power agenda by egging on attack groups, informing on concealed victims, and pillaging property from the dead.

Women describe being influenced by a subtle and complicated interplay between accepting their role as homemaker and compliant spouse and, at the same time, forming and acting on political beliefs in making decisions to participate in genocidal activities:

Respondent 10: [Women] were supporting their husbands to carry out killings. You may even find such women here in prison, who defend themselves by saying, "My husband was called upon to go to a road block, and do you think I could stop him?" or "My husband would ask me for his machete, and I knew where it was, so do you think I could refuse him?" Though you could not avoid doing it, why did you also cheer [the killers] on, or undress and plunder the victims? It was because you were happy that [Tutsis] were dying.

Respondent 8, a woman who reports feeling no personal animosity against Tutsis prior to the start of the 1990 civil war, is imprisoned for having denounced one of her Tutsi housemates at the outset of the genocide. Because Respondent 8 worked outside the home, she witnessed numerous episodes of harassment and arrest in the years leading up to the genocide and was accustomed to political discussion and debate.

Respondent 8: Life wasn't good at all [prior to 1994] because of the Interahamwe... [who] were stealing things from people who were coming from the market, especially those who looked like Tutsis... If you didn't have money to pay them they would throw your goods on the ground... I remember during the peace negotiations some leaders used to say that there wasn't enough space for all Rwandese, that it would be better if those who were outside the country did not come back. I think they killed Tutsis who were inside the country to discourage those who were outside from returning. Their interest made them to lead people into genocide.

Her family was poor, and Respondent 8 relied on the generosity of her neighbors to make ends meet. They lived in a neighborhood where Interahamwe also resided, and she was married to an Interahamwe member who died during the genocide. Although Respondent 8 never killed anyone herself, she was nevertheless forthright in describing her belief, in 1994, that all Tutsis and politically moderate Hutus were potential RPF collaborators and therefore a dangerous threat to the safety of Rwanda and Rwandans:

I considered them to be my enemies because they had killed our President and now they wanted to kill us. For me the wisest thing to do was to kill them... There were some Hutus who opposed the government, so they didn't kill and were treated as traitors, or spies for the Inkotanyi. I believed what was said about them. I considered them naïve. 
Thus, within the limits of a more traditional gender role, Respondent 8 encouraged and supported her husband, friends, and neighbors in prosecuting the genocide, even going so far as to return home, after fleeing her neighborhood for safety, in order to keep house for her husband:

When the fighting was approaching our neighborhood... we decided to go and seek refuge elsewhere... but my husband didn't stay there for long and he decided to return home. One day I met him coming to look for me. During the genocide my husband... wanted me back home.

During her interview, this respondent accepted responsibility for her actions and her contribution to advancing the genocide:

Men were more active in the killings, but women played a big role in the killings as well, because they could have advised their husbands not to kill innocent people.

Finally, despite constraining her behavior to norms that would have been acceptable for Hutu women during the 1973 persecution of Tutsis, Respondent 8 did not escape the scorn of family and society when her crimes became known:

When I went back home, my mother asked me if I wasn't feeling bad about things that I did in [the genocide]... and I told her that I never did anything bad... I don't know what they think now. Perhaps they think that I lied to them, [because] they don't come to see me.

Those who themselves killed victims were a small minority of Rwanda's women. Fewer than one in ten members of the Interahamwe militia were women who received "civil defense" training prior to the genocide. Because participation in hands-on violence was considered to fall outside gender-based norms for women in 1994, this small group of women not only took on the role of killer but also faced community censure for stepping outside traditional gender constraints. Some women who agreed to join the militias had reputations for challenging limits in other spheres and may have become involved precisely because of their familiarity with crossing social boundaries.

Respondent 10: There were some bad-mannered girls whose friends were Interahamwe. They must have walked together with their Interahamwe boyfriends and thus saw their deeds. When you keep on exchanging ideas with someone, you may find room within yourself to accommodate those ideas. That's why some women participated in the killings.

Of the ten women whose interviews are analyzed here, Respondent 7 was most forthcoming in describing the complex relationship between personal and external pressures driving her decision to kill at the outset of the genocide. Respondent 7 and her husband both joined the Interahamwe militia in the early 1990s. She reports being a heavy drinker and marijuana user prior to being recruited, activities that fall outside of the customary boundaries of "appropriate" behavior among Rwandan women even today. Respondent 7 received military and weapons instruction prior to the genocide and was told she was being prepared to go to war as well as to "exterminate Tutsis." Although never an enthusiastic supporter of Hutu Power herself, she responded to pressure from her husband to get involved in Interahamwe activities:

Respondent 7: There came a time when [my husband] tried to sensitize me [to Hutu Power ideology]... I then thought, "this is going to be difficult for me," but he told me that it was obligatory... Personally I never was on their side, but my husband once said to me, "If you don't take part, I will kill you myself." So I agreed to participate. 
Thus, with military training and a husband committed to the cause, in the early days of the genocide Respondent 7 agreed to kill a group of targeted civilians in her neighborhood. Traumatized by her actions and determined not to kill again, she nonetheless had difficulty withdrawing from Interahamwe attack groups:

They sent me to a homestead while armed with a rifle and when we surrounded the house I shot... people inside. I regretted it after I killed them. I knew that I had done something wrong and I felt that if I continued killing I would also die. I went home and told my husband how I had decided not to [kill again]. I told him, "these were my neighbors and their deaths have upset me, so I won't repeat [killing] anywhere else." He told me then, "If you don't continue... you will have to die also." ... Thereafter, I kept the rifle but avoided him.

Despite accepting non-traditional gender roles "for the sake of national defense," the few women who did receive militia training were not relieved of their customary responsibilities at home. Women combatants were expected to fulfill novel and traditional roles simultaneously, both while training with militias and, later, while participating in the genocide itself.

Respondent 7: Although they trained and sensitized me, I was never interested...I was trained for one month and then stopped. They then asked me, "Have you mastered it?" And I said, "Yes." I went home and continued my life, but when the war broke out they gave me a rifle and ordered me to kill people...

[Interviewer]: Why did you stop the weapons training sessions?

Respondent 7: I stopped because I had to take care of my children. I left them home alone and [the Interahamwe] wanted me to train into the evening hours ... The kids had nobody to feed them, so I decided to be there for my children.

Women who joined the Interahamwe placed themselves in a social and gender stratum without precedent in Rwandan traditions. Burdened with "double duty," women in the Interahamwe enjoyed neither the stature of full militia members, nor the welcome of their former supportive communities. It follows that our respondent in the militias reports feeling isolated from collective society, with few opportunities for guidance. As a result of such isolation, women who deliberately killed fellow Rwandans were not at all shielded from the resultant feelings of doubt, regret, or trauma.

Respondent 7: I always lived with guilt. I always thought about them. I asked myself why I killed them, but didn't find a reason, and regretted having done it... I thought, 'I "had no conflict with those people I killed, people with whom I shared even water, and who always chatted with me. Why did I kill them?" I started...looking for an elder who might have some insight into these feelings, and how [the Interahamwe] had incited me to become involved. But I found that even the elderly were afraid of being killed, and they wouldn't talk to me.

\section{Summary}

The results of this study reveal that for women, the decision to participate in the Rwandan Genocide was motivated by a complex interaction between background environmental themes that had been in play for years and contemporary experiential pressures that gathered momentum in or around April 1994.

In brief, Rwandan women's traditional environment of multiethnic, cohesive, and inter-reliant communities was undermined repeatedly in the postcolonial years and 
faced its greatest challenges between 1990 and 1994, during the RPF invasion, the implementation of multi-party politics, and the ascendancy of the Hutu Power movement. However, communities remained essentially intact until the downing of President Habyarimana's plane on 6 April 1994, an act that the Rwandan government blamed on the RPF in order to justify intensive militarization not only of the armed forces but of civil society as well. From this point on, the Hutu Power movement's campaign to eliminate Tutsis and Hutu political opponents engulfed virtually all social, interpersonal, and experiential aspects of the Rwandan reality, and this situation prevailed until the end of the war in July 1994.

April 1994 marked the culmination of months of covert planning by extremists; the reign of terror unleashed against Rwandan Tutsis and politically moderate Hutus was well organized and pre-planned by Hutu Power leaders. In the interests of "national security," civilians were called upon to murder Tutsi non-combatants, who were characterized as enemy collaborators and as a threat to national security. Average women experienced this as a true catastrophe and had the resultant reactions of terror, despondency, and, for some, rage and calls for revenge against all Tutsis. At the same time, women were terrified of the extremists who controlled national governance and their local communities, fearing that they or their children would be ensnared in the violence. Many aligned themselves with attack groups for protection or in order to be less "visible" to the extremists, who were threatening "Tutsi sympathizers." Others witnessed murders and were too fearful for their own safety to intervene. Women, who were ordered to stay at home through the crisis, had limited ability to gather information and thus to frame informed opinions about the violence unleashed in their communities.

As a result of the limits drawn by gender, some women describe participating in the genocide without substantial forethought and others describe their actions as inadvertent. However, some Rwandan women admit to participating deliberately and after considerable reflection. Such women believed the government propaganda that all Tutsis were RPF collaborators and spies, plotting with the RPF to murder and enslave Rwandan Hutus. For women not willing to breach traditional gender roles, participation was more "passive," including activities such as looting or denouncing hidden victims. Other women, perhaps with a history of transgressing gender boundaries in other aspects of community life, joined attack groups and actively murdered victims.

\section{Discussion}

From these data a picture emerges of how the "perfect storm" of violence came to pass and why the average Rwandan woman chose to become involved. The factors that were most influential in motivating each individual to participate evolved with the shifting, disturbing, and chaotic situation on the ground. Although there is no static case to draw from, it is possible to derive an aerial overview of why women chose to participate in the genocide and to understand the unique, gender-related experiences that informed those choices.

This is the first study to investigate the attitudinal risks for extreme violence that have the potential to be modified in public-health framework; as a result, there are few studies in the literature for comparison. However, some parallels may be drawn between our results and those from related fields of study.

Our finding regarding the sudden shift of women's attitudes after the 6 April 1994 "disaster" is echoed in the literature on women in neo-Nazi groups in the 
United States. In her interviews with thirty-four female racist activists, Kathleen Blee reports that for nearly all respondents, the "conversion" to racial activism was prompted by "a single dramatic life event," 47 such as a near-death experience or the loss of a loved one. Conversion stories took on the quality of moving from "naiveté to enlightenment," 48 much as Rwandan women rapidly aligned themselves with the Hutu Power movement after the death of Habyarimana.

The situation of Rwandan women in 1994 also resembles the circumstances of German women during the Third Reich. For example, far fewer women than men were direct participants in killing during the Nazi Holocaust. ${ }^{49}$ Similarly, just as their Rwandan counterparts a half-century later were admonished to stay indoors and take care of home and family, German women under the Nazis were also encouraged by official policy to confine their energies to Kinder, Küche, Kirche (children, kitchen, and church). ${ }^{50}$ Particularly after 1938, German women were charged with protecting a peaceful, supportive space for soldiers engaged in emotionally upsetting activities at the front. ${ }^{51}$ This concept reaffirms the themes conveyed by Respondents 7 and 8 in this study, who were expected to manage home and children while at the same time providing emotional support to husbands who spent their days "working" in attack groups.

Other resemblances also become apparent. Like our study respondents, some German women during the Third Reich refrained from forming political opinions, while others were steadfast supporters of Nazi doctrine and policy. ${ }^{52}$ In addition, Rwandan women's predilection for property crimes during the 1994 genocide was a reprise of German women's behavior during the Holocaust. Highly positioned German women-including Emmy Göring, wife of Chancellor Hermann Göring-engaged in "high-class" theft of the finest goods, homes, and lands expropriated from wealthy victims, while even "average" women, such as members of the Bund Deutscher Mädel (League of German Girls) willingly ejected Polish families from their farms, and looted homesteads for the best equipment, during their campaign to "resettle" ethnic German families from occupied territories. ${ }^{53}$

Both German and Rwandan women used genocide as an opportunity to step outside of traditional constraints and enter the conventional workforce. ${ }^{54}$ For example, the demands of rearmament and wartime economy called upon German women to take on traditionally "male" jobs in increasing numbers after 1936; in 1944, fully $57 \%$ of all German women were employed outside the home. Some wished to better their circumstances or advance themselves professionally, while others wished to escape the restraints imposed by more traditional roles. In Rwanda, too, a small number of women (such as Pauline Nyiramasuhuko) used the genocide as an opportunity to improve their financial circumstances or to advance "professionally" by assuming positions of authority during the time of upheaval.

Finally, it appears that the experiences of Rwandan women who themselves were part of the killing bureaucracy are also congruent with the experiences of German women in similar positions. Although there are few recorded interviews with women in the Schützstaffel (SS) available for comparison with Rwandan narratives, one example is Anna Fest, who was conscripted into service as a Ravensbrück guard in 1944 and was interviewed in the early 1990s. ${ }^{55}$ The wife of a foot soldier on the Russian front, Fest describes feeling helpless to refuse her given work assignment for fear of damaging her husband's standing and safety in the army.

Throughout extensive discussions, Fest continuously describes herself as naïve, or as having blinders on, for not wanting to see that although no women under her guard 
died while she worked at Ravensbrück (a fact that appears to be historically accurate), the conditions there were designed to slowly annihilate inmates. ${ }^{56}$ Only after Fest was subjected to a 100-mile "death march" in 1945 did she come to see the goals of the Final Solution as they really were and to rebel against them by assisting victims and publicly accusing the SS officer in charge of murder. Fest's commentary recalls the themes inherent in the narrative of Respondent 9, a low-level Rwandan government official (cellule leader) in 1994 who admits to having detained and guarded neighbors who were rounded up and eventually killed by Interahamwe leaders from another part of her city. Although Respondent 9 herself never harmed anyone personally, she turned over her charges to the killers without protest, reportedly "not realizing" what would happen to them once she did. After this incident, Respondent 9 reports, she felt shocked and despondent. She spent the rest of the genocide hiding a group of targeted children in her home; all of them went on to survive into adulthood.

\section{Conclusion}

As the international community (outside of a handful of courageous African nations) fails to intervene in known episodes of genocide that continue at the time of this writing, ${ }^{57}$ statesmen, academics, and human-rights workers have accelerated the public debate on approaches to genocide prevention that might prove more effective in current and future conflicts. However, this discussion has tended to conflate long-term efforts toward primary prevention of genocide (what The Responsibility to Protect calls studying and addressing the contributory root causes of catastrophic violence) with emergency military, diplomatic, and economic "prevention" at the point when large-scale atrocities have already begun ("reaction to catastrophic violence," in the language of The Responsibility to Protect). ${ }^{58}$ This mixing of terminology has confused the discussion of genocide prevention, to its detriment, and has focused the international community on crises that are already out of control by the time adequate attention is paid. Regrettably, late-phase approaches-although necessary-have not been effective in preventing genocide in such countries as Rwanda, Bosnia, and Sudan, and it is apparent that new strategies for the prevention of catastrophic violence are in order. The introduction of sociological tools that predict societies at high risk for catastrophic violence now makes it possible to target vulnerable societies years in advance of an emergency. ${ }^{59}$ The science of public health is uniquely situated to enter this discussion with synergistic, longer-range, primary approaches to violence prevention that have proved durable over the past twenty years.

The objective of the ARC-G agenda is to identify attitudinal patterns among potential genocide perpetrators that may be amenable to modification, years in advance of provocations by genocidal governments. The data presented here demonstrate that it is possible, in a retrospective sample of genocide perpetrators, to ascertain the attitudes and beliefs that drive average citizens to tacitly support, actively encourage, or thoroughly involve themselves in genocidal violence. In the immediate next steps of the ARC-G agenda, researchers will attempt to ascertain, through similar methods in real time, the attitudes and beliefs that drive individuals who are currently involved in episodes of extreme violence.

However, no effort of primary genocide prevention, no matter how long-range, can be successful without targeting women and girls, as well as men and boys, in well-researched programs of attitudinal change. The fact that women and girls suffer the highest casualties during episodes of collective armed conflict has been demonstrated by a growing body of recent scholarship. ${ }^{60}$ In spite of this, the critical 
role of women in supporting, promoting, and perpetrating episodes of collective violence must not be overlooked. Women create nurturing environments for husbands, sons, and brothers to rejuvenate from the trauma of mass killing and, in so doing, may be seen as complicit in this crime. ${ }^{61}$ Women cheer on killers from the sidelines. Women are likely to be the main perpetrators of property crimes against targeted victims across genocidal outbreaks. Ultimately, a small percentage of women have participated in hands-on assault and murder in all documented instances of genocide. $^{62}$

The societal pressures that drive women and girls to participate in genocide are by no means identical to those that drive men and boys within the same society. ${ }^{63}$ Health-education campaigns targeting violence prevention will succeed in proportion to how well the pressures pushing each segment of the population are understood and how carefully health messages are crafted to reach each individual sector of the community. It is not difficult to imagine crafting long-range educational programs targeting female as well as male civilians in order to engender attitudes and behaviors that are resistant to provocation by genocidal governments when disaster strikes. Along similar lines, it is also possible to envision crafting media broadcasts targeted specifically at relatively homebound women during times of national catastrophe, in order to supply them with accessible information, balanced reportage, and strategies for successful resistance to the pressure to engage in human-right abuses and crimes.

The data on women's tendency toward more "gender-consonant" crimes such as looting or denouncement have not been explored fully with respect to genocide but have been the subject of extensive research in other settings where women commit crimes. This may prove a promising avenue of research, in that there is a substantial body of literature to draw on for future genocide-prevention initiatives targeted at the very much neglected population of young and older women who are drawn into all aspects of extreme population-based violence.

Finally, it is important to add that the approaches put forward by the ARC-G research agenda are designed to be synergistic with other later-phase military, diplomatic, and economic approaches to genocide prevention and cessation. The necessary and sufficient structural conditions that predispose societies to outbreaks of catastrophic violence have been discussed elsewhere ${ }^{64}$ and will be repeated here only to point out that, from the broadest perspective, genocide is considered a crime of governments against their citizens. However, while non-democratic governments may incite their populations to attack unarmed civilians, and specific social conditions may exacerbate the inclination of groups to lash out, it is self-evident that, in any genocide, individuals support and carry out the actual killing. The conclusion may be drawn that any organized, scientific approach to genocide prevention will be incomplete without a long-range strategy for transforming genocide predictors in individuals and groups on the ground.

The data reported here represent a preliminary step in developing a more complete understanding of the roles that young and older women play in catastrophic violence, as well as in defining what a public-health-based approach to long-range, primary genocide prevention might look like. The object of future inquiry will be to test whether it is possible to apply this approach in incipient conflict zones and whether implementation of health-education campaigns, developed from similar data in a contemporary setting, will have the desired effect of lowering rates of violence in high-risk jurisdictions. 


\section{Acknowledgments}

The authors recognize the following individuals for their invaluable contributions in carrying out the research reported in this paper.

Advisory Committee: Dr. Odette Nyiramilimo, Senator, Republic of Rwanda; Ms. Fatuma Ndangiza, Executive Secretary, National Unity and Reconciliation Commission, Republic of Rwanda; Mr. Jean de Dieu Mucyo, Prosecutor General, Supreme Court, Republic of Rwanda; Mr. François Ngarambe, Head, IBUKA (National Survivor's Association), Rwanda; Mr. Joseph Habineza, Minister of Youth, Sport and Culture, Republic of Rwanda; Mr. Apollon Kabahizi, Former Country Director, Aegis Trust, Rwanda.

Research Team: Robert Fiedler, Emmanuel Kabahizi, Alphonse Rulinda, Geraldine Umutesi, Alice Uwera, Innocent Nkunda Munyarugerero, Pothin Kabahizi, Eric Ngangare, and Ibrahim Murobafi.

This research was funded by the J. William Fulbright Scholarship Board/US Department of State (Dr. Adler); the University of British Columbia Office of the Vice President, Research; and the Vancouver Coastal Health Authority Office of Research Affairs.

\section{Notes}

1. R.J. Rummel, Statistics of Democide: Genocide and Mass Murder since 1900 (New Brunswick, NJ: Transaction, 1998).

2. J. Fowler, "Beyond Humanitarian Bandages: Confronting Genocide in Sudan," New England Journal of Medicine 351 (2004): 2574-76.

3. Reva N. Adler, James Smith, Paul Fishman, and Eric B. Larson, "To Prevent, React, and Rebuild: Health Research and the Prevention of Genocide," Health Services Research 39 (2004): 2027-51.

4. D.K. Conn, D. Clarke, and R. Van Reekum, "Depression in Holocaust Survivors: Profile and Treatment Outcome in a Geriatric Day Hospital Program," International Journal of Geriatric Psychiatry 15 (2000): 331-37; L. Eitinger and A. Strom, "New Investigations on the Mortality and Morbidity of Norwegian Ex-Concentration Camp Prisoners," Israel Journal of Psychiatry Related Sciences 18 (1981): 173-95; O. Gronvik and A. Lonnum, "Resultant Neurological Conditions in Former Concentration Camp Prisoners," Tidsskrift for Den Norske Lægeforening 81 (1961): 808-10; K. Kuch and B.J. Cox, "Symptoms of PTSD in 124 Survivors of the Holocaust," American Journal of Psychiatry 149 (1992): 337-40; Ariela Yaari, Elon Eisenberg, Rivka Adler, and Jesmon Birkhan, "Chronic Pain in Holocaust Survivors," Journal of Pain and Symptom Management 17 (1999): 181-87;

Rachel Yehuda, James Schmeidler, Milton Wainberg, Karen Binder-Brynes, and Tamar Duvdevani, "Vulnerability to Posttraumatic Stress Disorder in Adult Offspring of Holocaust Survivors," American Journal of Psychiatry 155 (1998): 1163-71.

5. Christopher R. Browning, "Genocide and Public Health: German Doctors and Polish Jews, 1939-41," Holocaust and Genocide Studies 3, 1 (1988): 21-36; M. Carballo, S. Simic, and D. Zeric, "Health in Countries Torn by Conflict: Lessons from Sarajevo," Lancet 348 (1996): 872-74; Richard Horton, "Croatia and Bosnia: The Imprints of War-I. Consequences," Lancet 353 (1999): 2139-44.

6. Adler et al., "Prevent, React, Rebuild."

7. Julie Flint and Alexander DeWaal, A Short History of a Long War (London: Zed Books, 2006).

8. J. Leaning, "Diagnosing Genocide: The Case of Darfur," New England Journal of Medicine 351 (2004): 735-38.

9. Gareth Evans and Mohamed Sahnoun, co-chairs, The Responsibility to Protect: Report of the International Commission on Intervention and State Sovereignty (Ottawa:

International Development Research Centre, 2001); Etienne G. Krug, Linda L. Dahlberg, 
James A. Mercy, Anthony B. Zwi, and Rafael Lozano, eds., World Report on Violence and Health (Geneva: World Health Organization, 2002).

10. N.G. Guerra and R.G. Slaby, "Cognitive Mediators of Aggression in Adolescent Offenders: 2. Intervention," Developmental Psychology 26 (1990): 269-77.

11. Susan D. McMahon and Jason J. Washburn, "Violence Prevention: An Evaluation of Program Effects with Urban African American Students," Journal of Primary Prevention 24 (2003): 43-62.

12. David R. Meddings, Lyndee M. Knox, Matilde Maddaleno, Alberto Concha-Eastman, and Joan Serra Hoffman, "World Health Organization's Teach-Vip: Contributing to Capacity Building for Youth Violence Prevention," American Journal of Preventive Medicine 29 (2005): 259-65.

13. Henry Victor Dicks, Licensed Mass Murder: A Socio-psychological Study of Some SS Killers (London: Heinemann Educational/Sussex University Press, 1972); Robert Jay Lifton, The Nazi Doctors: Medical Killing and the Psychology of Genocide (New York: Basic Books, 1986).

14. Adler et al., "Prevent, React, Rebuild."

15. Graeme R. Newman, ed., Global Report on Crime and Justice (New York: Oxford University Press/ United Nations Centre for International Crime Prevention, 1999).

16. Cynthia Cockburn, "The Gendered Dynamics of Armed Conflict and Political Violence," in Victims, Perpetrators or Actors? Gender, Armed Conflict and Political Violence, ed. Fiona C. Clark and Caroline O.N. Moser, 13-29 (London: Zed Books, 2001).

17. Erin Baines, "Body Politics and the Rwandan Crisis," Third World Quarterly 24 (2003): 479-93.

18. Adam Jones, "Gender and Genocide in Rwanda," Journal of Genocide Research 4 (2002): $65-94$.

19. Susan McKay, "The Effects of Armed Conflict on Girls and Women," Peace and Conflict: Journal of Peace Psychology 4 (1998): 381-92; Binaifer Nowrojee, Shattered Lives: Sexual Violence during the Rwandan Genocide and Its Aftermath (New York: Human Rights Watch, 1996); Meredeth Turshen, "The Political Economy of Rape: An Analysis of Systematic Rape and Sexual Abuse during Armed Conflict in Africa," in Victims, Perpetrators or Actors? Gender, Armed Conflict and Political Violence, ed. Fiona C. Clark and Caroline O.N. Moser, 55-68 (London: Zed Books, 2001); C. Watts and C. Zimmerman, "Violence against Women: Global Scope and Magnitude," Lancet 359 (2002): 1232-37.

20. Christopher Browning, Ordinary Men: Reserve Police Battalion 101 and the Final Solution in Poland (New York: HarperPerennial, 1993); Dicks, Licensed Mass Murder; Lifton, Nazi Doctors; Eric Markusen and Damir Mirkovic, "Understanding Genocidal Killing in the Former Yugoslavia: Preliminary Observations," in Collective Violence: Harmful Behavior in Groups and Governments, ed. Craig Summers and Eric Markusen, 35-67 (Lanham, MD: Rowman \& Littlefield, 1999).

21. Cockburn, "Gendered Dynamics."

22. Ibid.; Helen Fein, Genocide: A Sociological Perspective (London: Sage Publications, 1993).

23. Helen Fein, "Models of Genocide and Critical Responses," in Toward the Understanding and Prevention of Genocide: Proceedings of the International Conference on the Holocaust and Genocide, ed. Israel W. Charny, 3-31 (Boulder, CO: Westview Press, 1984); Barbara Harff, "A Theoretical Model of Genocides and Politicides," The Journal of EthnoDevelopment 4 (1993): 25-30; Robert Melson, Revolution and Genocide: On the Origins of the Armenian Genocide and the Holocaust (Chicago: University of Chicago Press, 1992).

24. Frank Robert Chalk and Kurt Jonassohn, The History and Sociology of Genocide: Analyses and Case Studies (New Haven, CT: Yale University Press, 1990); Leo Kuper, Genocide: Its Political Use in the Twentieth Century (London: Penguin, 1981); Mel McNulty, "French Arms, War and Genocide in Rwanda," Crime, Law and Social Change 33 (2000): 105-29.

25. Browning, "Genocide and Public Health"; Claudia Koonz, The Nazi Conscience (Cambridge, MA: Belknap Press, 2003); Lifton, Nazi Doctors. 
26. Mahmood Mamdani, When Victims Become Killers: Colonialism, Nativism and Genocide in Rwanda (Princeton, NJ: Princeton University Press, 2001). The four-party coalition formed to defeat Habyarimana's Mouvement Révolutionnaire National pour le Développement et la Démocratie (MRND) consisted of the Mouvement Démocratique Républicain (MDR), affiliated with the peasantry of central Rwanda; the center-left Parti Social-Démocrate (PSD), representing the multicultural intelligentsia; the Parti Libéral (PL), which eschewed ethnic politics and appealed to Tutsis and Rwandans of mixed parentage; and the Parti Démocrate-Chrétien (PDC), which struggled to find a political base.

27. African Rights, Rwanda - Not So Innocent: When Women Become Killers (London: African Rights, 1995); Jones, "Gender and Genocide"; Lisa Sharlach, "Gender and Genocide in Rwanda: Women as Agents and Objects of Genocide," Journal of Genocide Research 1 (1999): 387-99.

28. African Rights, Not So Innocent; Ligue Rwandaise pour la promotion et la defense des droits de l'homme [Ligue Rwandaise], Situation des droits de la personne au Rwanda en 2002: rapport annuel de la Liprodhor (Kigali: Ligue Rwandaise, 2003).

29. African Rights, Not So Innocent.

30. International Criminal Tribunal for Rwanda, Status of Cases: NYIRAMASUHUKO, Pauline (ICTR-97-21), http://69.94.11.53/ENGLISH/cases/Nyira/index.htm (accessed 10 August 2007).

31. Nicole Hogg, "Women Accused of Genocide in Rwanda," Women's Rights in Conflict Situations Newsletter, http://www.dd-rd.ca/site/publications/

index.php?lang $=$ en\&subsection $=$ catalogue\&id=1272\&page $=7 \#$ (accessed 10 August 2007).

32. Ligue Rwandaise, "Situation des droits."

33. Amnesty International, Rwanda: The Enduring Legacy of the Genocide and War (AI Document AFR 47/008/2004, 2004), http://web.amnesty.org/library/pdf/

AFR470082004ENGLISH/\$File/AFR4700804.pdf (accessed 10 August 2007; "World Law: Rwanda," Jurist, ed. Bernard J. Hibbitts (University of Pittsburgh School of Law), http:// jurist.law.pitt.edu/world/rwanda.htm (accessed 10 August 2007).

34. Anselm L. Strauss and Juliet M. Corbin, Basics of Qualitative Research: Grounded Theory Procedures and Techniques (Newbury Park, CA: Sage, 1990).

35. United Nations Educational, Scientific and Cultural Organization [UNESCO], "Regional Overview: Sub-Saharan Africa," in Gender and Education for All: The Leap to Equality (EFA Global Monitoring Report 2003/4) (UNESCO, 2004), http://www.unesco.org /education/efa_report/zoom_regions_pdf/ssafrica.pdf (accessed 13 August 2007).

36. International Telecommunication Union [ITU], Table 1: Basic Indicators (ITU, 2004), http://www.itu.int/ITU-D/ldc/pdf/basicindicators_2004.pdf (accessed 13 August 2007).

37. Ministry of Local Government, Community Development and Social Affairs, Republic of Rwanda, Administrative Map of Rwanda 2005, http://www.minaloc.gov.rw/admin_terri tory/images/adminmap_rwanda1.gif (accessed 13 August 2007).

38. Grant McCracken, The Long Interview (Newbury Park, CA: Sage, 1988). This four-stage approach involves (1) a thorough review of all relevant background literature; (2) an introspective inventory of the researcher's grasp of the research questions; (3) the interview, during which participants tell their story; and (4) analysis of the aggregate data for emerging themes.

39. Michelle Peters and Jan Passchier, "Translating Instruments for Cross-Cultural Studies in Headache Research," Headache 46 (2006): 82-91.

40. McCracken, Long Interview.

41. Strauss and Corbin, Basics of Qualitative Research.

42. Sharlach, "Gender and Genocide."

43. African Rights, Not So Innocent.

44. No one has ever been brought to justice for downing Habyarimana's plane, and controversy continues regarding who is responsible. Although French judge Jean-Louis Bruguière 
alleges that current Rwandan president (and former RPF general) Paul Kagame ordered the attack, it is far from certain that Bruguière has sufficient evidence to make his case. For his part, President Kagame has struck a Rwandan national commission headed by former justice minister Jean de Dieu Mucyo to investigate the role of the French in the murder of Habyarimana as well as in colluding with the Hutu Power government to prosecute the genocide. The controversy continues as of this writing.

45. Roméo Dallaire with Brent Beardsley, Shake Hands with the Devil: The Failure of Humanity in Rwanda (Toronto: Random House, 2003); Alison Des Forges, Leave None to Tell the Story (New York: Human Rights Watch, 1999).

46. Gerald Caplan, Rwanda: The Preventable Genocide (Addis Ababa, Ethiopia: Organization of African Union, 2000), www.visiontv.ca/RememberRwanda/Report.pdf (accessed 13 August 2007); Chalk and Jonassohn, History and Sociology of Genocide; Fein, "Models of Genocide"; Barbara Harff and Ted R. Gurr, "Victims of the State: Genocides, Politicides and Group Repression since 1945," International Rewiew of Victimology 1 (1989): 23-41; Eric Markusen, "Genocide, Total War and Nuclear Omnicide," in Genocide: A Critical Bibliographical Review, ed. Israel W. Charny, 229-63 (New York: Facts on File, 1991); Melson, Revolution and Genocide; Ervin Staub, The Roots of Evil: The Origins of Genocide and Other Group Violence (New York: Cambridge University Press, 1989).

47. Kathleen M. Blee, "Becoming a Racist: Women in Contemporary Ku Klux Klan and Neo-Nazi Groups," Gender and Society 10 (1996): 680-702, 689-90.

48. Ibid., 689 .

49. Gisela Bock, "Ordinary Women in Nazi Germany," in Women in the Holocaust, ed. Dalia Ofer and Lenore J. Weitzman, 85-100 (New Haven, CT: Yale University Press, 1998).

50. Ibid.; Elizabeth Harvey, Women and the Nazi East: Agents and Witnesses of Germanization (New Haven, CT: Yale University Press, 2003); Claudia Koonz, "Consequences: Women, Nazis and Moral Choice," in Different Voices: Women and the Holocaust, ed. Carol Rittner and John K. Roth, 287-308 (St. Paul, MN: Paragon House, 1993); Mathew Stibbe, "Women and the Nazi State," History Today 43, 11 (1993): 35-40.

51. Claudia Koonz, Mothers in the Fatherland: Women, the Family, and Nazi Politics (New York: St. Martin's Press, 1987).

52. Koonz, "Consequences"; Adelheid von Saldern, "Victims or Perpetrators: Controversies about the Role of Women in the Nazi State," in Nazism and German Society, 1933-1945, ed. David F. Crew, 141-65 (London: Routledge, 1994).

53. Bock, "Ordinary Women"; Harvey, Women and the Nazi East; Koonz, Mothers in the Fatherland.

54. African Rights, Not So Innocent; Jack G. Morrison, Ravensbrück: Everyday Life in a Women's Concentration Camp, 1939-45 (Princeton, NJ: Markus Wiener, 2000).

55. Alison Owings, Frauen: German Women Recall the Third Reich (New Brunswick, NJ: Rutgers University Press, 1993).

56. Ibid., 313-41.

57. Flint and DeWaal, Short History; Gérard Prunier, Darfur: The Ambiguous Genocide (Ithaca, NY: Cornell University Press, 2006); Samuel Totten and Eric Markusen, Genocide in Darfur: Investigating Atrocities in the Sudan (New York: Routledge, 2006).

58. Evans, Responsibility to Protect.

59. Barbara Harff, "Risk Assessment and Early Warning" (paper presented at the Stockholm International Forum, Preventing Genocide-Threats and Responsibilities, Stockholm, 26-28 January 2004).

60. Les Roberts, Riyadh Lafta, Richard Garfield, Jamal Khudhairi, and Gilbert Burnham, "Mortality Before and After the 2003 Invasion of Iraq: Cluster Sample Survey," Lancet 364 (2004): 1857-64.

61. Koonz, Mothers in the Fatherland. 
62. Jones, "Gender and Genocide"; Koonz, Mothers in the Fatherland; Roger Smith, "Women and Genocide: Notes on an Unwritten History," Holocaust and Genocide Studies 8 (1994): 315-34.

63. Reva N. Adler, Judith Globerman, Cyanne E. Loyle, and Eric B. Larson, "Transforming Men into Killers: Risk Factors for Hands-On Violence during the 1994 Rwandan Genocide" (unpublished manuscript, 2006); Cockburn, "Gendered Dynamics"; Dicks, Licensed Mass Murder; Lifton, Nazi Doctors; Sharlach, "Gender and Genocide."

64. Chalk and Jonassohn, History and Sociology of Genocide; Fein, "Models of Genocide"; Harff, "Theoretical Model"; Kuper, Genocide; Markusen, "Genocide, Total War"; Melson, Revolution and Genocide. 